\title{
Revision of town planning in the Pioverna basin by the use of a multidisciplinary study to identify flood-prone areas: Valsassina, Lombardy Region, Northern Italy
}

\author{
F. Luino ${ }^{1}$, J. V. De Graff ${ }^{2} \&$ P. Fassi ${ }^{3}$ \\ ${ }^{1}$ Consiglio Nazionale delle Ricerche, Istituto di Ricerca per \\ la Protezione Idrogeologica (CNR-IRPI), Torino, Italy \\ ${ }^{2}$ USDA Forest Service, Clovis, USA \\ ${ }^{3}$ Regione Lombardia-Coordinamento Servizio H24, \\ Sala Operativa Protezione Civile, Milano, Italy
}

\begin{abstract}
This case study examines 10 municipal areas of the Pioverna River valley bottom (Valsassina, Northern Italy). Flood-prone areas were identified using historical research and geomorphological analysis. The historical research for different areas utilized records from the State technical office archives, Ministry of Public Works, Hydrographical Offices of the Po River, Civil Engineers, Records Office, public libraries, local and national newspapers archives, and municipal archives. Large amounts of historical data on past floods were collected, reviewed and validated on map flood-damaged locations. A geomorphological analysis was also conducted in which multi-temporal aerial photographs were studied and field surveys conducted to verify the reliability of the historical data and the planform changes of the Pioverna River course. The analysis of historical and geomorphological data produced a flood-prone area map with two different hazard zones identified along the Pioverna River. Aerophotogrammetric and cadastral maps were used to verify and update the urban planning of the 10 municipalities studied. The mosaic map of the urban planning shows four classes of land-use destinations, as defined according to the different levels of building exposure. On a matrix, the four land-use classes were matched to flood hazard sites of the two zones along the Pioverna River. The resulting map defines five classes of different flood risk. The results of the
\end{abstract}


study have been used to verify present land-use planning and to start a review process of the existing urban plans and/or their general changes.

Keywords: flood-prone areas, multidisciplinary study, damage, Alps.

\section{Introduction}

The use of historical data can aid in conducting an accurate geomorphological study of an area. Documents about past floods provide a valuable source of evidence to forecast future flood limits and prevention of instability processes [1]. The historical analysis of a river's floods can reveal the fluvial stretches where the banks were repeatedly overtopped and the lands more frequently flooded. Historical analysis also shows that when a previously unflooded area is inundated, it is often due to the presence of new human works that have changed the natural evolution of the land [2]. To identify present day flood prone-areas, the land transformations from past decades, including consideration of all manmade structures, must be studied. Sometimes, historical data are sufficiently plentiful to generate useful statistics on space-time changes in processes. Suitable processing of data in combination with geomorphological surveys can provide valuable information about the past, so that future floods can be better forecasted and their expected occurrence included in land-use planning.

\section{Geographical context, geomorphological setting and hydrography of the study area}

The study area is located in Lombardy; northwest of the Lecco. The purpose of this study was to analyse the territories of 10 municipalities crossed by the course of the Pioverna River in the Prealps of Lecco. From upstream to downstream the municipalities are: Cremeno, Barzio, Pasturo, Introbio, Primaluna, Cortenova, Taceno, Vendrogno, Parlasco and Bellano (Fig. 1). Connections between the main towns in the valley developed along the valley bottom with a principal route being the Provincial Road No. 62 of Valsassina, which joins Lecco with Bellano.

The basin of the Pioverna River represents an area thoroughly studied from a geological point of view due the presence of tectonic flakes in the coverage of the Prealps, represented by the group of Grigne-Resegone. They are imbricate elements, with a certain lateral continuity. The western sector of the basin is structurally affected by three important thrust of the northern Grigna and southern Grigna and Coltignone.

In more recent geological history, the Valsassina suffered an important modification to the path of Pioverna River. Prior to the Pleistocene, the river flowed from north to south, in the direction of Lecco. This is evidenced by the conglomerates of the Balisio Hill, where the imbricate deposits provide indications on the direction of the current. Middle Pleistocene tectonic movements brought a change in the structure of the valley which results in a diversion of the Pioverna to the north. 
From a geomorphological point of view the Valsassina presents itself as a glacial valley with the U-shaped profile and hanging valleys, such as that of Troggia Stream, which flows into the main valley with a morphological step near Introbio. The morphology of the valley is not homogeneous along the entire section and it is possible to identify three zones. In the first section from the Balisio Hill to the confluence with the flow coming from Barzio, the main valley is steep and the Pioverna River sometimes flows in a deep rocky bed. In the second section to the Tartavalle Bridge, a wide valley is present characterized by the alluvium deposited by the river and its tributaries: this section is characterized, in its upper part to the Ponte Chiuso, by the presence of a large plain due to an ancient dammed lake. In the last, and third, section, from

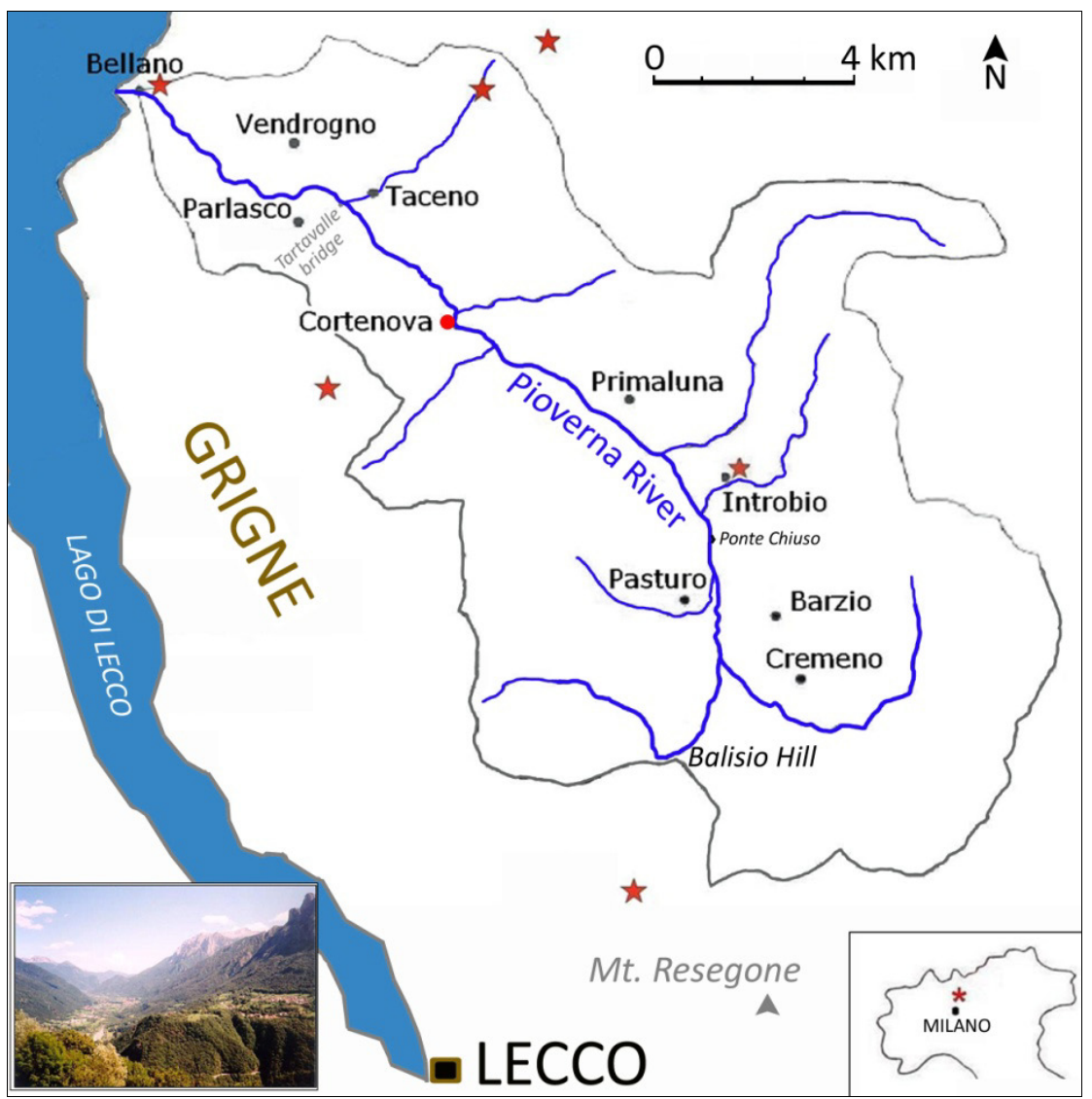

Figure 1: Map of the Valsassina with the analysed towns; red stars indicate the rain gauge locations. In the corner, the panorama of the Valsassina between Taceno and Cortenova villages (figure by Luino). 
Tartavalle to Bellano, the valley is very narrow and the river flows in a gorge until the spectacular gorge of Bellano, located less than a kilometre from the access to the Lake of Lecco.

The Pioverna River rises from Grigne at an altitude of about $1100 \mathrm{~m}$, in the Pasturo territory. After a path of about $27 \mathrm{~km}$ flows at the eastern shore of the Lago di Lecco, near the town of Bellano, at an altitude of about $200 \mathrm{~m}$. Its catchment area covers a total area of about $150 \mathrm{~km}^{2}$. The Pioverna has a dense hydrographic network with at least 8 dangerous streams concentrated mainly draining the southwest-facing slopes. One of eight is the Rossiga Stream in the Cortenova territory which frequently producing hazardous mud-debris flows including a notable flow that occurred in November 2002.

\section{Applied methodology}

The study was carried out in three phases: 1) historical research of past flooding data; 2) geomorphological study by field survey and aerial photograph analysis; 3) urban planning analysis.

\subsection{Historical research of past flooding data}

The historical analysis began with the consultation of the information stored in the rich Archive and library of the CNR-IRPI of Turin. The investigation there examined all volumes of geomorphology and hydrology, hydraulic studies, local history and also conference proceedings [3-5]. Particular attention has also been devoted to the Annals of the Ufficio Idrografico (Hydrographic Office), although unfortunately the measurement network is rather lacking in Valsassina.

Additional documents were collected from 1970 to the present, at thirty public bodies (especially the Ministry of Public Works) and at major State archives: usually these were unpublished documents. Having completed the collection of such documents, the search started at specific municipal archives which allowed unpublished information of great importance to be found including unpublished reports on past floods, their dynamics and timing, flooded areas, water levels and maps of inundation. Documents classified under "Public works" can contain information about past floods and references to the inundated areas, casualties, and sometime the amount of damages. From the thousands of documents consulted, the dates and sites of the inundations were collected and listed in a table

The municipal archives of the ten villages were the best source of historical information. In each municipal archive the documents classified under "Public works" can contain information about past floods and references to the inundated areas, casualties, and sometimes the amount of suffered damages. From the thousands of documents consulted, the dates and sites of the inundations were collected and listed in a special table. This information was supplemented by culling through at large collection of newspapers (1800-today) with national and local circulation. This required careful work to extract relevant news dealing with the floods. In some instances, municipal libraries held papers, technical and 
historical books regarding the Pioverna Valley which proved useful. Each report about past flood events was entered into a catalogue file containing 19 terms, from the event code to the coordinates of the damaged site. Each file corresponds to a symbol linked to an alphanumerically coded label on the map (scale at $1: 10.000)$. The symbols differ in form and colour to show general or exact location of the damaged site (structure, infrastructure, stretch, etc.) (Fig. 2). The symbol is a red dot if the document referred to an exact location of the damaged site. A yellow triangle at the midpoint of a bank or a damaged road indicates the document made no clear reference to a stabilization work or a road. A green square next to the name of the village shows the document gave only general information on the area struck by a flood. The historical findings, based on 341 reports, showed that 99 floods occurred in the period 1800-2000. By subdividing this record into 20-year periods suggests that the number of flood events is increasing from 1800 to today, in particular from 1941.

This apparent increase may be explained by any one or combination of three factors: a) loss of historical documents (fires, floods, transfers, burglaries, etc.); b) increase of modern information sources; c) spread of urbanised areas on the valley bottom and so greater likelihood of their being involved during flood events. Of the flood events for which the exact year and month are known (81), nearly half $(45.7 \%)$ occurred in summer, with June and August ranking as the most frequent months (13).

Differences in "level of magnitude" were identified based on the number of municipal areas inundated and the number of reports found (Table 1). This criterion does not take into account the severity of the damage, because the economic value of a damaged structure or infrastructure is difficult to quantify from historical analysis. The June 23-24, 1951, the July 17-19 1987 and the August 27-28, 1996 were the most catastrophic and best documented event of the past 200 years, with respectively 6,7 and 6 municipalities damaged. Covering an important area in the middle sector of the Valsassina [6], the territory of Cortenova (1295 inhabitants) has been impacted at least 19 times (18 sites damaged) in the course of the last two centuries (Table 2 and Fig. 2).

Table 1: $\quad$ Level of magnitude of the Pioverna and tributaries flood events.

\begin{tabular}{|c|c|c|}
\hline $1^{\circ}$ level of magnitude & $\frac{2^{\circ} \text { level of magnitude }}{}$ & $\frac{3^{\circ} \text { level of magnitude }}{}$ \\
\hline & November 1801 & July 1825 \\
June 23-24,1951 & October 2-4, 1851 & August 24-25, 1844 \\
July 17-19,1987 & July 16, 1985 & Autumn 1896 \\
August 27-28, 1996 & September 25-26,1993 10,1954 \\
& June 27-28,1997 & October 3, 1976 \\
& & October 29-30,1976 \\
& June 21-22, 1996 \\
\hline
\end{tabular}


Table 2: $\quad$ List of past floods of Cortenova municipal territory: code, date, water course and damaged site are shown.

\begin{tabular}{|c|c|c|c|c|c|}
\hline Code & \multicolumn{3}{|c|}{ Date } & Water course & Locality involved \\
\hline & Year & Month & Day/s & & \\
\hline & 1801 & 11 & & $\begin{array}{l}\text { Pioverna River, San } \\
\text { Biagio Stream, Rossiga } \\
\text { Stream }\end{array}$ & $\begin{array}{l}\text { Bindo, Fucine, Cugnolo, } \\
\text { Cortenova (S.P.) }\end{array}$ \\
\hline $3 \mathrm{Wa}$ & 1825 & 07 & & $\begin{array}{l}\text { Pioverna River, Val dei } \\
\text { Molini Stream, S. Biagio } \\
\text { Stream }\end{array}$ & $\begin{array}{l}\text { Prato S. Pietro (bridge), } \\
\text { Bindo (bridge), Cortenova }\end{array}$ \\
\hline $18 \mathrm{~Wb}$ & 1843 & 06 & 29 & Rossiga Stream & Road Cortenova-Cortabbio \\
\hline & 1844 & 08 & $24-25$ & Pioverna River & Bindo \\
\hline $75 \mathrm{~W}$ & 1903 & & & Rossiga Stream & Cortenova \\
\hline $113 \mathrm{Wd}$ & 1911 & 08 & 21 & Rossiga Stream & $\begin{array}{l}\text { Downstream of the } \\
\text { confluence between Piale } \\
\text { Creek and Rossiga Stream }\end{array}$ \\
\hline $76 \mathrm{~W}$ & 1927 & 08 & 24 & Val dei Molini Stream & Prato S. Pietro \\
\hline $25 \mathrm{~Wb}$ & 1944 & 07 & 21 & Rossiga Stream & Cortenova \\
\hline $24 \mathrm{~W}$ & 1947 & 07 & $8-9$ & Pioverna River & Cortenova (main square) \\
\hline $\begin{array}{l}78 \mathrm{Wa} \\
78 \mathrm{~Wb} \\
78 \mathrm{Wc}\end{array}$ & 1951 & 06 & 23 & $\begin{array}{l}\text { Rossiga Stream, San } \\
\text { Biagio Stream, Val dei } \\
\text { Molini Stream }\end{array}$ & $\begin{array}{l}\text { Cortenova, Bindo, Prato S. } \\
\text { Pietro (bridge) }\end{array}$ \\
\hline $\begin{array}{l}11 \mathrm{Wa} \\
11 \mathrm{~Wb} \\
11 \mathrm{Wc} \\
11 \mathrm{Wd}\end{array}$ & 1951 & 11 & 09 & Pioverna River & $\begin{array}{l}\text { Valgrande; upstream Bindo; } \\
\text { Cortenova }\end{array}$ \\
\hline $79 \mathrm{Wa}$ & 1965 & 09 & $1-3$ & Rossiga Stream & Cortenova \\
\hline $42 \mathrm{~Wb}$ & 1966 & & Imn & Pioverna River & $\begin{array}{l}\text { Cortenova municipal } \\
\text { territory }\end{array}$ \\
\hline $\begin{array}{l}81 \mathrm{Wa} \\
81 \mathrm{~Wb}\end{array}$ & 1979 & 10 & $16-17$ & Pioverna River & $\begin{array}{l}\text { Bindo (camping), Bindo } \\
\text { (right bank) }\end{array}$ \\
\hline $82 \mathrm{Wa}$ & 1982 & 06 & $12-14$ & Pioverna River & Bindo (right bank) \\
\hline $94 \mathrm{Wd}$ & 1985 & 07 & 16 & Val dei Molini & $\begin{array}{l}\text { Prato S. Pietro (confluence } \\
\text { with Pioverna) }\end{array}$ \\
\hline $\begin{array}{l}95 \mathrm{Wg} \\
95 \mathrm{Wh}\end{array}$ & 1987 & 07 & $18-19$ & Pioverna River & $\begin{array}{l}\text { Bindo (left bank), Bindo } \\
\text { (right bank) }\end{array}$ \\
\hline $\begin{array}{l}101 \mathrm{Wd} \\
101 \mathrm{Ws} \\
101 \mathrm{Wt} \\
101 \mathrm{Wu} \\
101 \mathrm{Wz}\end{array}$ & 1996 & 08 & $27-28$ & $\begin{array}{l}\text { Pioverna River, V. San } \\
\text { Biagio Stream, V. dei } \\
\text { Molini Stream, Rossiga } \\
\text { Stream }\end{array}$ & $\begin{array}{l}\text { Cortenova (downstream } \\
\text { bridge), Grattarola, Bindo, } \\
\text { Prato S. Pietro, Cortenova } \\
\text { (prov. Road) }\end{array}$ \\
\hline $71 \mathrm{Wg}$ & 1997 & 06 & $27-28$ & Pioverna River & Cortenova \\
\hline
\end{tabular}

\subsection{Geomorphological study by field survey and aerial photograph analysis}

The geomorphological analysis was carried in two closely related parts. First, the evolution of the Pioverna River during the last fifty years was retraced by indepth photointerpretation analysis of multi-temporal different aerial images. During the second part, the reliability of the historical data and the interpretation of the aerial photographs were verified by field surveys along the Pioverna riverbed. The existing works such as bridges, footbridges, dikes, thresholds, and 


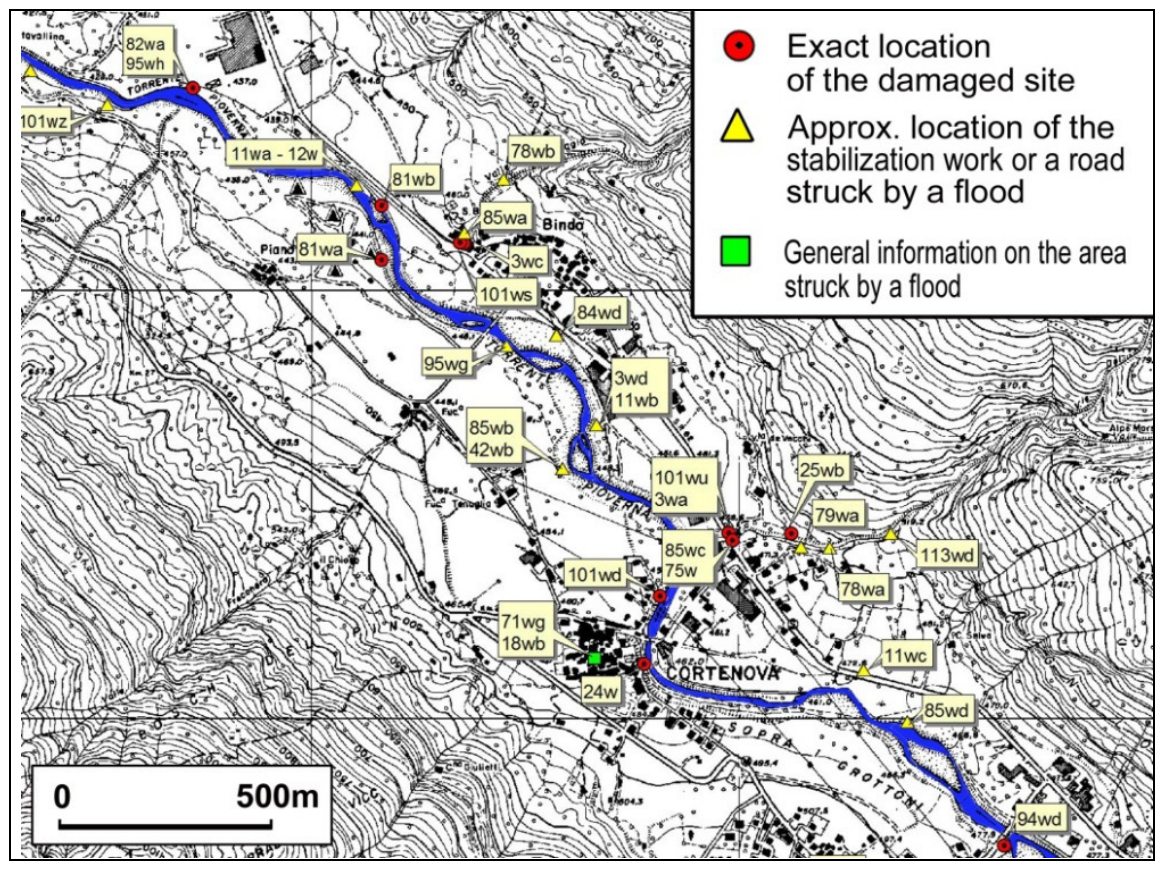

Figure 2: Past damage map of the Cortenova municipal area. Each alphanumerically coded label refers to a historical file (figure by Luino and Fassi).

embankment walls were also examined and photographed and their state of conservation and function noted.

The morphological survey along the Pioverna riverbed defined the boundaries of the flood-prone areas and compared with the flooding which occurred during the last significant events: 18-19 July 1987, 27-28 August 1996 and 27-28 June 1997. The areas and of their boundaries outside the riverbed were identified on the basis of the field survey and the available historical evidence. Maps and technical comments in the hydraulic reports of various companies were taken into account during the identification process.

The flood-prone areas shown on 8 maps, (scale 1:10000), are based on the Regional Technical Map (CTR) (Fig. 3). Red oblique sketching defines corridor 1 , outside the riverbed includes the position of the restorable river forms (old pathway channels), which are the areas usually inundated in the past. These limits correspond to morphological differences in ground level or to hydraulic flood control works [7]. The corridor 2, outside corridor 1 , is defined by vertical green sketching. It includes a portion of territory which could be hit by a "catastrophic" flood. The limits are defined by morphological elements (high terraces, rock walls, etc.). 


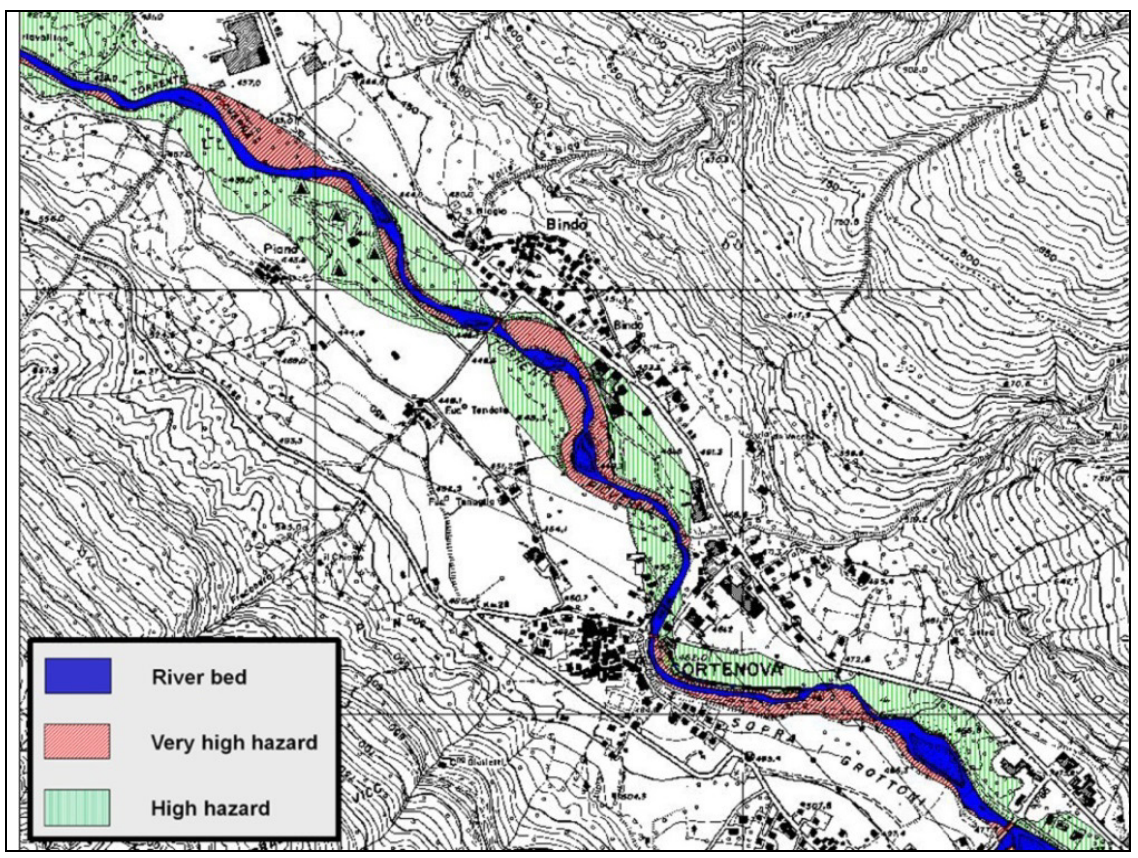

Figure 3: Geomorphological map of the Pioverna valley bottom for the Cortenova municipal area is representative of the maps produced for the Valsassina (figure by Luino and Fassi).

\subsection{Urban planning analysis: the mosaic map}

The aim of the analysis was to improve knowledge of the existing building property and to define criteria of compatibility with the future urban development. The urban planning of the ten municipalities in the area between Cremeno and Bellano were analysed and then unified. Only six villages (Pasturo, Introbio, Primaluna, Cortenova, Taceno and Bellano) are located along the Pioverna river bed: the other four are situated close the tributaries.

In the first phase, cartographic representations of the urban plan displaying technical codes in force were collected (scale 1:2000 and 1:5000). Because many gaps exist due to the lack of up-to-date uniform reference cartography, a synthesis map (scale of 1:5000) was compiled to provide a standardized base map of existing and expected land-use. Also, it permitted a comparison between the past and present urban situations of the little villages of the Valsassina. The maps were required for the synthesis map included both existing and planned land use decisions for expansion of residential, industrial/manufacturing, tourism/hotel, agriculture, and green spaces. For each municipality, a careful analysis was carried out which created a grouping of land uses for areas adjacent to the river and the confluence with the tributaries.

The area has been extensively transformed, partly by the expected projects of the urban plans in force, and partly by proposals where construction of new 
buildings is closely linked to the development of tourism to the valley. The effect of tourism has included considerable population increases during some periods of the year.

The mosaic map of the urban plans (Fig. 4) shows the areas of land use, which were combined into 8 categories defined by their principal functions:

a) Residential settlement (yellow): existing and expected residential areas; b) Hotel/Residences and Tourist Facilities (purple): tourist facilities (residences, hotels, spas, etc.); c) Public Services Areas (orange): municipal buildings, barracks, schools and hospitals, churches, dumping areas and storage platforms, purification plants, etc.); d) Industrial and Handicraft Areas (red): existing and expected industrial, craft-made and commercial buildings; e) Sport Areas, Utilities and Standards (green): public gardens, parks, athletics grounds, private and public sport clubs, golf course, etc.). All areas occupied by roads, railways and cemeteries are marked in the same colour; f) Agricultural Areas (light brown) agricultural activities. In these areas old farms can be renovated and the building volume slightly expanded; g) Woods (dark green): grassland, pastures, and h) Fluvial Zones (blue): natural areas along the river banks defined as safeguards of the watercourses by the urban plans.

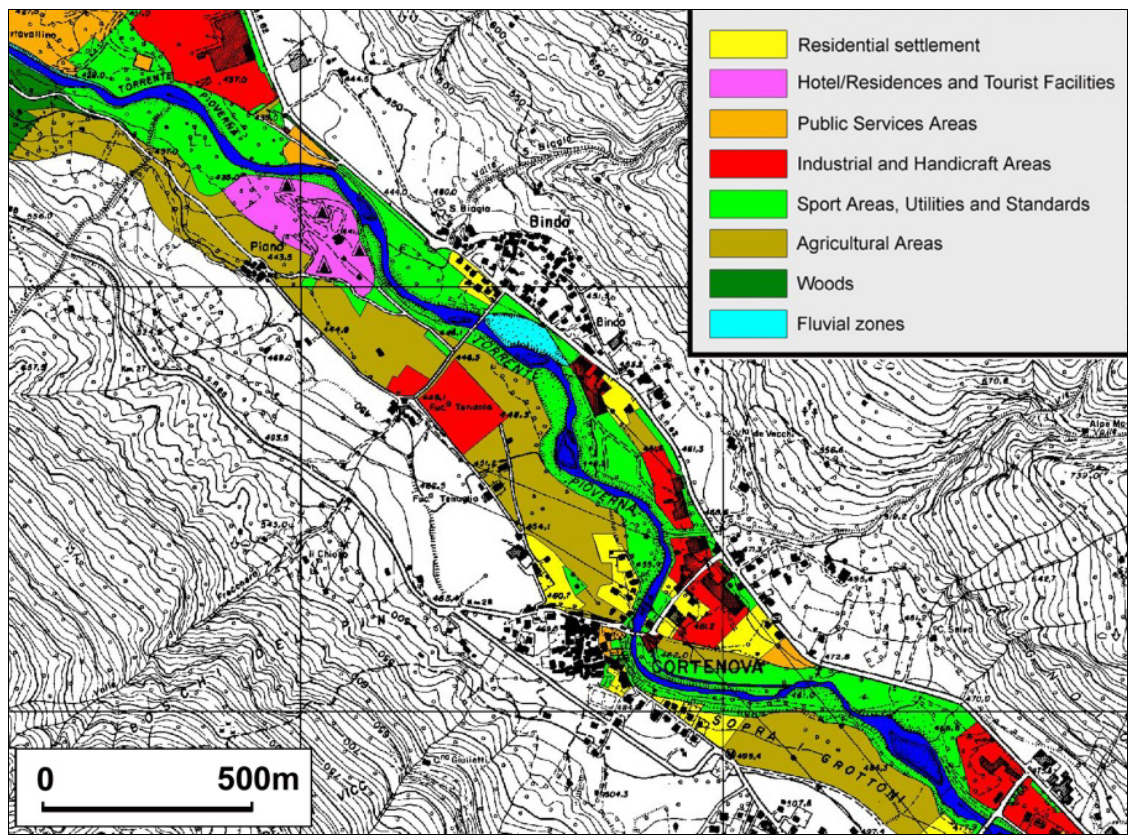

Figure 4: Urban planning mosaic map of the Cortenova municipal area (figure by Luino and Fassi). 


\subsection{Definitive map of the areas with different flood risk}

The differences among land uses necessitated categorizing for their potential exposure to flood hazard before flood risk could be assessed. The eight categories were further combined into 4 classes according to the following parameters: a) presence or concentration of people over 24 hours or at particular hours of the day, b) presence of machineries or properties, c) presence of socialrecreational activities and/or loss of profit from damage to the agricultural zones and d) presence of environmentally valuable areas.

On the basis of these parameters, the 4 classes were assigned an exposure rating: $\mathrm{HIGH}$ level = residential settlement, hotel/residences and tourist facilities; MEDIUM level = public services areas and industrial and handicraft areas; LOW level $=$ the sport areas, utilities and standards and agricultural areas; VERY LOW level $=$ woods and fluvial zones. By classifying a territory and subdividing it into uniform urbanised and land use zones, a qualitative assessment can be made to evaluate the potential damage a certain hazard may cause. To obtain the quantitative risk level to which a territory is exposed, a more detailed scale should be used and should incorporate a structural survey to evaluate the reaction of single buildings and their structural characteristics, i.e. their vulnerability to damage.

Along the Pioverna river, in the two flood-prone areas identified earlier by the geomorphological analysis are located: a) new residential dwellings and tourist facilities characterized by inhabited ground level flats or underground garages; b) industrial and handicraft areas; c) camping grounds located in environmentally attractive zones; d) farms and farmhouses of the property owners (often built without particular controls) and storages of materials or dumps located along the banks that an inundation could remove, provoking security and hygienic sanitary problems.

A "risk matrix" (Fig. 5) has allowed a consistent correlation between the exposure level of the urbanized zones and the hazard (very high and high) of the two flood prone areas along the river. By imposing the urban plan mosaic map on the geomorphological map, the areas with the highest risk along the Pioverna valley are highlighted (Fig. 6). With this classification of the territory, subdivided into homogeneous urbanized and land use zones, it is possible to evaluate the damage that a future event may cause, with a qualitative evaluation.

\section{Conclusions}

The combination of historical investigation and geomorphological analysis appears to be an interesting and useful method for identifying flood-prone areas. A detailed knowledge of past floods can allow us to identify and to delimit with high confidence the areas most exposed to flood hazard and to define for different zones of the territory the return time of an event.

Statistically, historical research indicates flood frequency has clearly been increasing in the Valsassina during the period 1801-2000. This increase may be "real" because of the growth of anthropic pressure, throughout all Alpine valleys. This urbanization has taken away large natural areas from water courses. Today 


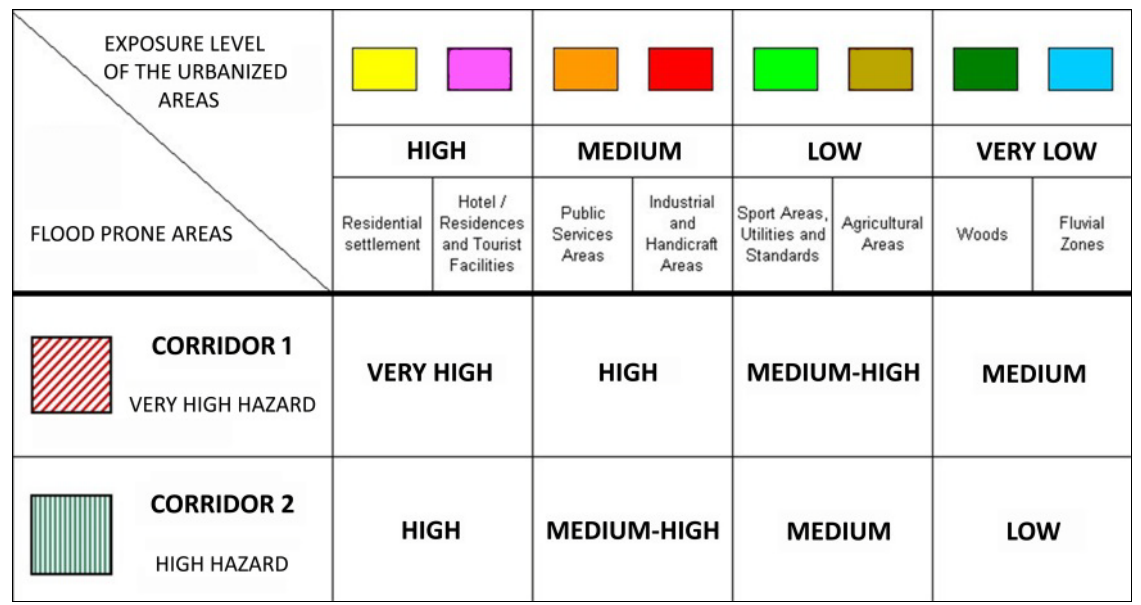

Figure 5: Matrix of territorial risk used along the Pioverna River (figure by Luino and Fassi).

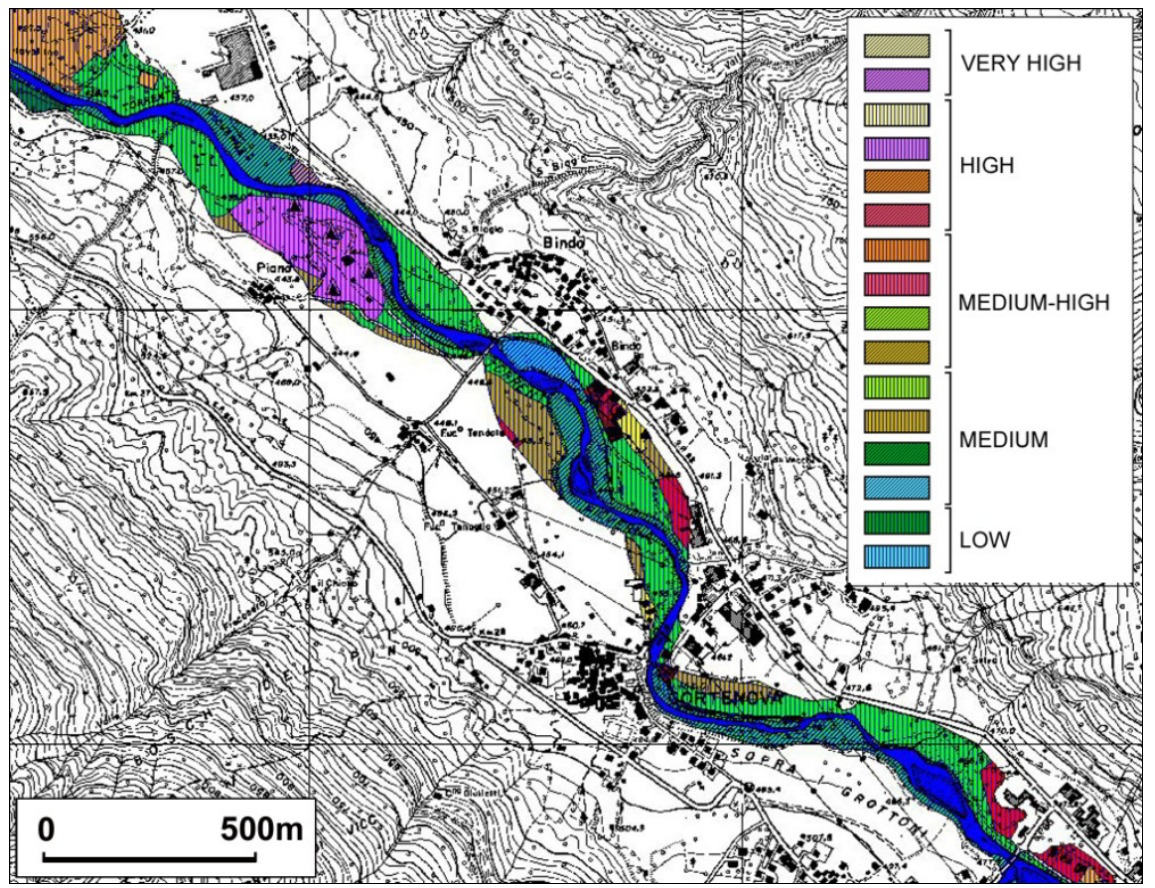

Figure 6: The final map shows the areas of the Cortenova municipality with the highest risk levels along the Pioverna valley bottom (figure by Luino and Fassi). 
many torrents and rivers are "obliged" to flow within restricted sections, which are clearly inadequate for exceptional flow discharges. However, the increase in the number of floods could also be an artifact due to the lack of older documents that does not permit a comprehensive perspective on a period of two or more centuries.

The historical research started from a specific request of the technical public bodies in the control of land use planning. The purpose was to gain a retrospective view of the old events in order to better manage the territory. This view was achieved. The superimposition of the urban planning mosaic map on the historical-geomorphological maps has proven to be an essential step in identifying the areas with the highest land critical levels from a flooding point of view. The results can be used as guidelines for a revision of urban planning and in particular for future urban development.

But the best risk assessment results must necessarily forecast a comparison with the present conditions of the territory, taking into account the natural changes and all transformations produced by man-made works (in particular presence of new levees, road and railway embankments, enlargement of urbanized areas). This comparison can be done with an additional hydraulic study which has its own limitation. Only with a multidisciplinary approach is it possible to collect a very large amount of information identifying the most important factors [8]. Based on this broad knowledge, operators can intervene on the continuous and fast evolution of the environment by having a dynamic rather than static vision of the territory.

\section{References}

[1] Caroni E., Maraga F. \& Turitto O. (1990) - La delimitazione di aree soggette a rischio di inondazione: un approccio multidisciplinare. Atti del XXII Convegno di Idraulica e costruzioni idrauliche. Cosenza, 4-7 ottobre 1990, Vol. III, 9-21.

[2] Luino F., Bassi M., Fassi P., Belloni A. \& Padovan N. (2002) "L'importanza delle notizie pregresse quale supporto allo studio geomorfologico per l'individuazione delle aree potenzialmente inondabili ai fini urbanistici: il fondovalle del Torrente Pioverna (Valsassina, Lombardia)". Italian Journal of Engineering Geology and Environment, Quaderni di Geologia Applicata - Serie AIGA, 1, 95-109.

[3] Arrigoni G. (1840) - Notizie storiche della Valsassina e delle terre limitrofe dalla più remota età fino all'anno 1844. Appendice dal 1844 in avanti. Milano, Ed. Pirola, 87.

[4] Brasi P.A. (1823) - Memoria storica intorno alla Valle Seriana superiore. Ed. Rovetta, 56-57.

[5] Orlandi A. (1995) - Memorie di Pasturo e Bajedo in Valsassina. Amministrazione Comunale di Pasturo, 371.

[6] Baio F. \& Bonalumi G. (1993) - Studio geologico tecnico del territorio del Comune di Cortenova a supporto del piano regolatore generale. Amministrazione Comunale di Cortenova, 52. 
[7] Turitto, O., Maraga, F., Luino, F. (1995). Impatto sulle infrastrutture viarie prodotto da piene con inondazione. Atti $1^{\circ}$ Convegno Nazionale di Geologia Applicata, Giardini Naxos 11-15 June 1995, 77-90. N. pubbl. GNDCI 1390.

[8] Govi, M., Serva, L., Turitto, O. (1990). La conoscenza delle piene storiche nelle valutazioni di sicurezza e di protezione del territorio. Sicurezza e Protezione, 8, n. 23-24, 12-23. 